Asian-Australasian Journal of

Food Safety and Security

ISSN 2523-1073 (Print) 2523-2983(Online)

www.ebupress.com/journal/aajfss

\title{
Article \\ Comparative analysis of nutritional quality of different fish feed available in greater Noakhali region, Bangladesh
}

\author{
Mir Abu Nayeem ${ }^{1}$, Amir Hossain ${ }^{1 *}$, Mahidi Hossen Hannan $^{2}$ and Subrata Mondal ${ }^{3}$ \\ ${ }^{1}$ Department of Fisheries and Marine Science, Noakhali Science and Technology University, Noakhali-3814, \\ Bangladesh \\ ${ }^{2}$ National University, Gazipur-1704, Bangladesh \\ ${ }^{3}$ Department of Fisheries and Marine Bioscience, Faculty of Biological Science and Technology, Jashore \\ University of Science and Technology, Jashore-7408, Bangladesh
}

*Corresponding author: Amir Hossain, Department of Fisheries and Marine Science, Noakhali Science and Technology University, Noakhali-3814, Bangladesh. Phone: +8801723623962; E-mail: fish44230@bau.edu.com

Received: 01 April 2019/Accepted: 05 May 2019/ Published: 30 May 2019

\begin{abstract}
An experiment was carried out to comparative analysis of nutritional quality of different fish feed from different feed dealers and industries in greater Noakhali region and to compare the values with those provided by the manufacturers. The feed samples were collected from different feed industries and dealer's shop of these region. Feed samples were collected during 10 August to 5 September, 2016. The collected feed samples were stored and analyzed in the Fish Nutrition Laboratory of the Department of Aquaculture in the Faculty of Fisheries, Bangladesh Agricultural University (BAU), Mymensingh for proximate composition (moisture, ash, crude protein, crude lipid, crude fiber, carbohydrate) following standard methods. Results showed that there was significant variation between analyzed and company provided nutritive values of different feeds. Some feed samples have low moisture level (difference 0.7 to 3.3\%). Ash content of the experimental samples also show a variety of results compared to their labeled composition. Only some feed have more values to the company provided values, such as, Mega starter (12.13\%) and Bengal grower (12.75) proportion with $12 \%$. Some feed contains more difference range of $6.01 \%$ more than labeled values is RP feed (20.01\%). Maximum feed samples had lower crude protein (difference 0.05 to $4.65 \%$ ) than the company provided protein values. However, only crude protein of Bengal finisher (29.95\%) and Aftab grower (28.07\%) feeds were found to be almost same to the company provided nutritive values (30\% and 28\%). The lipid, ash and carbohydrates contents of the experimental samples also have a difference range. The highest lipid values are available in Provita starter $(9.76 \%)$ and lowest values containing feed Setu grower $(4.33 \%)$. The highest carbohydrates content in the feed Provita starter (36.84\%). The findings of this study demonstrated that low quality commercial fish feeds were supplied to the fish farmers by majority of feed companies. Therefore, the study will generate some information to the farmers which will help to choose the best feed for their aquaculture production.
\end{abstract}

Keywords: nutritional quality; fish feed; Noakhali; Bangladesh

\section{Introduction}

Bangladesh is tremendously diversified with fishes and fisheries. According to report of FAO, (2016) in 2014 and 2015, Bangladesh took 5th Place in Inland Fish Production and 6th in total Aquaculture production. Bangladesh exports 83,524 mt of fish \& fisheries products, price of this quantity is BDT 4,660.60 million Tk. This sector is contributing $1.92 \%$ of the total export earnings and $3.69 \%$ to the GDP. The contribution in GNP is BDT 19567.90 crore Tk, and contribution to agricultural sector is $23.12 \%$ (DoF, 2016). The people of 
Bangladesh depend on fish for $60 \%$ of their animal protein. In Bangladesh fish consumption rate is $19.71 \mathrm{~kg} /$ people/ year. Total demand of fish is 37.65 lakh mt per year and demand per person $21.90 \mathrm{~kg}$ per year (DoF, 2016). To fulfill the increasing demand of fish for food and decline in capture fisheries production, Aquaculture is heading towards intensification. That's why, it's consequently leading to an unprecedented rise in the demand for feeds. Fish feed plays an important role in the value chain as it implies important control of the quality of raw materials, which is crucial for the food safety as well as efficient high quality feed types that ensures optimal growth for different fish species farmed under a variety of different conditions. Economically productive aquaculture systems depend upon an adequate supply of low cost feeds with high nutritional quality. The major cost in the fish industry is feed; it contributes about $40 \%-60 \%$ of total cost in fish culture. The nutritional quality of fish feed and the ingredients that are used in feed formulation as well as nutritional composition of finished goods or formulated diets are very sensitive issues in the field of fish nutrition. Nutrition and feeding play an important role in the sustained development of the aquaculture. Therefore, it is obligatory that feed resources continue to be produced and refined. There are a variety of commercial fish feed are available in Bangladesh. Some of the common feed are- Nursery feed, Pre-Starter feed, Starter feed, Grower feed, Finisher feed of different fish species like as Tilapia, Pangas, Carp, Koi, Sing, Magur and other fish species. These feed will very effective for growth and production rate of fishes if the nutritional value of these feed are accurate and perfect. Demand of fish feed is increasing day by day and number of fish feed companies are also increasing. There are a significant number of Feed Company are available in Bangladesh especially in Noakhali region. Noakhali region is a fertile land for Fish production, because of its geological status. For this reason, many renowned feed industries produce fish feed at this region. Some of the top Company are Glove Agrovet Limited, Bengal Feed and Fisheries Ltd, Partex Fish Feed Ltd, Mega Fish Feed, R.P Feed, Setu Feed, Provita feed etc. These industries not only manufacture fish feed but also they produce livestock feed such as poultry, cattle, pet animal etc. On the other hand, hundreds of small-scale non-commercial and on-farm feed industries produce fish feed throughout the country. There is a shortness of information on the nutrient content of fish feed produced by different feed industries in Bangladesh, as well as greater Noakhali region. There are also no reliable published information on composition of manufactured fish feed in Bangladesh. The farmers have to depend only on the existing information about the feed composition and growth performance that is given by the feed industry. The importance of fish feed is increased with the intensification of aquaculture. However, commercial fish production fully depends on quality feed. Feed costs generally constitute the highest single operation cost of semi-intensive or intensive grow-out farming operation. It is therefore of great importance to the fish farmers to utilize their investments in feed as optimal as possible. Different NGOs and Extension Agencies working for aquaculture extension in Bangladesh are interested to know about the nutritive value of commercial fish feed of Bangladesh (Asif et al., 2014; Islam et al., 2014; Asif et al., 2015; Islam et al., 2015; Rahaman et al., 2015; Sharif et al., 2015; Sultana et al., 2015; Hossain et al., 2016b; Vaumik et al., 2017; Razeim et al., 2017; Islam et al., 2017a; Asif and Habib, 2017; Hossain et al., 2018; Mondal et al., 2018 and Adhikary et al., 2018;). Government has a legal legislation but still has very less or no control over feed industries of Bangladesh. The government has no legal legislation and control over the feed components and feed quality. There are also no guidelines for the establishment of a new feed industry. There is no monitoring by the government on the quality and nutrient content of feeds produced by different feed manufacturers, even if there is a possibility to use unauthorized feed ingredients and they do not maintain proper quality in manufacturing feed. Therefore it is an urgent need to assess the comparative analysis and actual nutritional quality of the feed available in the market. So these areas were selected for this comparative analysis, which will be able to represent the availability and nutritional quality of fish feed of the region. Therefore the present study was conducted to evaluate the fish feed industries of Noakhali region; to collect and find out the locally available fish feed details with feed type, ingredients sources, labeled nutrient contents and cost; to analyses the proximate composition of collected fish feed available in these feed mill to evaluate the nutritional value; to compare the nutritional composition with their labeled nutrient contents.

\section{Materials and Methods}

\subsection{Experimental site and collection of fish feed samples}

The experiment on nutritional quality analysis of different fish feed was conducted for the period of three months from August, 2016 to October, 2016. A large number of fish feeds were available in greater Noakhali produced by commercial feed mills and industries. The most popular commercial fish feeds available throughout the Noakhali region were Bengal Feed, Globe Agrovet Feed, RP Feed, Setu Feed, Partex Feed, Quality Feed, Provita Feed, Mega Feed, Nurani Ready Feed, Aftab Feed, Abis Feed. A total of 18 feed samples of 11 feed companies were collected. All of the feeds used in this study were collected from feed industries and 
feed dealers' shops by the author himself. Duplicate same types feed samples of those selected 11 feed companies were collected two weeks later. After collection of feed samples, the samples were kept in a refrigerator and then transported to the fish nutrition laboratory, Department of Aquaculture, Bangladesh Agricultural University (Figure 1).

\subsection{Laboratory facilities}

The analysis of feed was carried out in the Fish Nutrition Laboratory of the Department of Aquaculture in the Faculty of Fisheries, Bangladesh Agricultural University (BAU), Mymensingh. The laboratory has available facilities for the determination of proximate composition viz. moisture, crude protein, crude lipid, ash, crude fiber and carbohydrate.

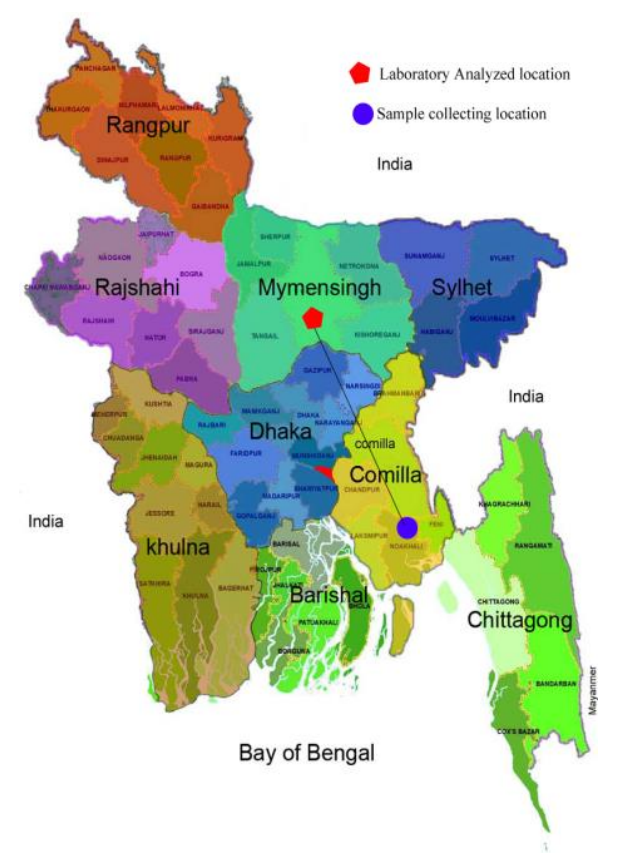

Figure 1. Map showing the sample collecting and analyzing location.

\subsection{Analytical methods}

\subsubsection{Estimation of moisture}

The change of weight is estimated under certain temperatures. Moisture of fish is commonly determined by drying a sample at some elevated temperature and reporting the loss in weight in terms of moisture (AOAC, 2000).

\subsubsection{Determination of ash}

Ash is the residues of the inorganic matter (mineral) of the sample after burning. If the sample in a muffle furnace at $600^{\circ} \mathrm{c}$ the organic matter is evaporate and residues are called ash. Ash content of each feed was estimated by following incineration method (Maynard, 1970).

\subsubsection{Determination of crude protein}

According to Kjeldhal methods proteins are hydrolyzed to amino and withH2SO4. Further heating decomposes the amino acid releasing- Ammonia which immediately trapped on (NH4)2SO4 and water. Micro kjeldhal method was to determine the crude protein (Jacobs MB, 1973; Mitchell P, 1972; Pearson et al., 1977 and Bhuiyan et al., 2016).

\subsubsection{Determination of crude lipid}

Fat is examined with low boiling organic solvent (petroleum ether/ diethyl ether, xylem) by soxhlet extraction and the extract thus obtained weighed after recovery of the solvent. Crude fat was determined through Soxhlet extraction technique (Maynard, 1970 and Jacobs, 1973) using hexane $\left(65^{\circ} \mathrm{C}-70{ }^{\circ} \mathrm{C}\right)$ as the solvent. 


\subsubsection{Determination of crude fiber}

The A small amount of finely ground sample (1-2 g) was taken in to a filter crucible and was inserted into the hot extraction unit (Hot Extractor, Model-1017). Sufficient amount of pre-heated 0.128M H2 SO4 was added into the reagent heating system and few drops of octanol were added through the valves. The mixture was digested for 30 minutes. Acid was then removed from it by filtering and washing with boiling water. The residue in the flask was boiled with required amount of $0.223 \mathrm{M} \mathrm{KOH}$ for 30 minutes and then filtered with subsequent washing in boiling water and acetone. The residual content was then dried in an oven at $105^{\circ} \mathrm{C}$ for a few hours and then ignited in muffle furnace at $550^{\circ} \mathrm{C}$ for 3 hours. The loss of weight represented the crude fiber.

\subsection{Data processing and analysis}

After collection of data, these were edited and coded. All the collected data were summarized and scrutinized carefully and recorded. Finally relevant tables were prepared in accordance with the objectives of the study. Data presented mostly in the tabular form because it is simple in calculation, widely used and easy to understand, soft word and Microsoft excel were used for data analysis and for chart, graph diagram preparation.

\section{Result}

\subsection{Nutritive value of commercial feeds}

In the experiment proximate composition of 18 feeds such as moisture, protein, lipid, ash, crude fiber and carbohydrate were analyzed in the laboratory (Table 1).

Table 1. Name of the feed companies.

\begin{tabular}{|c|c|c|}
\hline Sl. No & Company Name & Type of feed \\
\hline 1 & Partex Feed & Starter \\
\hline 2 & Partex Feed & Finisher \\
\hline 3 & Globe Agro vet & Nursery \\
\hline 4 & Globe Agro vet & Grower \\
\hline 5 & Bengal Feed & Starter \\
\hline 6 & Bengal Feed & Grower \\
\hline 7 & Bengal Feed & Finisher \\
\hline 8 & Setu Feed & Starter \\
\hline 9 & Setu Feed & Grower \\
\hline 10 & R P Feed & Grower \\
\hline 11 & Mega Feed & Nursery \\
\hline 12 & Mega Feed & Starter \\
\hline 13 & Mega Feed & Finisher \\
\hline 14 & Aftab Feed & Grower \\
\hline 15 & Provita Feed & Grower \\
\hline 16 & Nurani Feed & Starter \\
\hline 17 & Quality Feed & Nursery \\
\hline 18 & Abis Feed & \\
\hline
\end{tabular}

\subsection{Moisture content}

In the conduct experiment a total of 18 feed samples were analyzed to know the actual moisture content. Some feed samples contain more or less similar moisture percentage as these were labeled by the manufacturer. Others are found having deviated composition from their labeled value. The analyzed mean moisture content of fish feed varied from $9.3 \%$ to $15.33 \%$. The highest moisture containing feed was RP grower feed. It contained $15.33 \%$ moisture. Mean moisture content of Mega finisher feed was $12.14 \%$ which was nearly same to labeled moisture (12\%). The lowest mean moisture content in Mega Starter feed was 9.3\% compared to the labeled moisture content $(10 \%)$ having a difference of $2.57 \%$. The analyzed results of different feed samples were shown in the Figure 2 (starter), and Figure 3 (grower). 


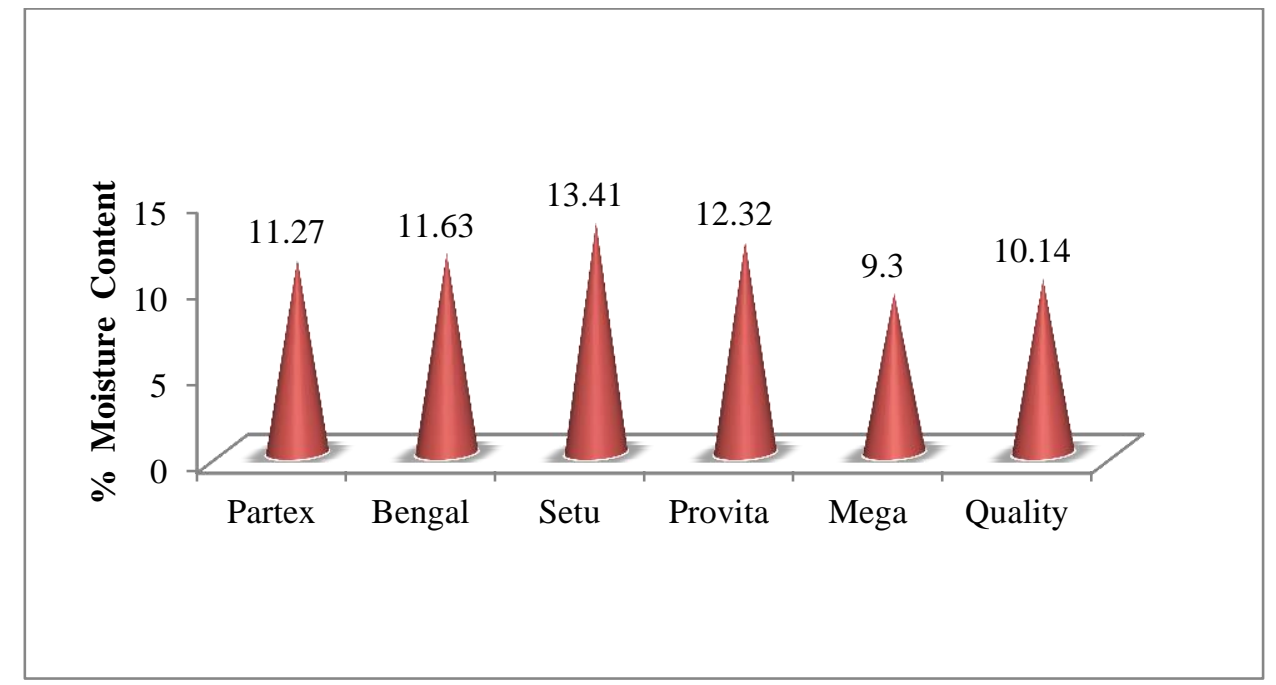

Figure 2. Moisture content of starter feeds of different companies.

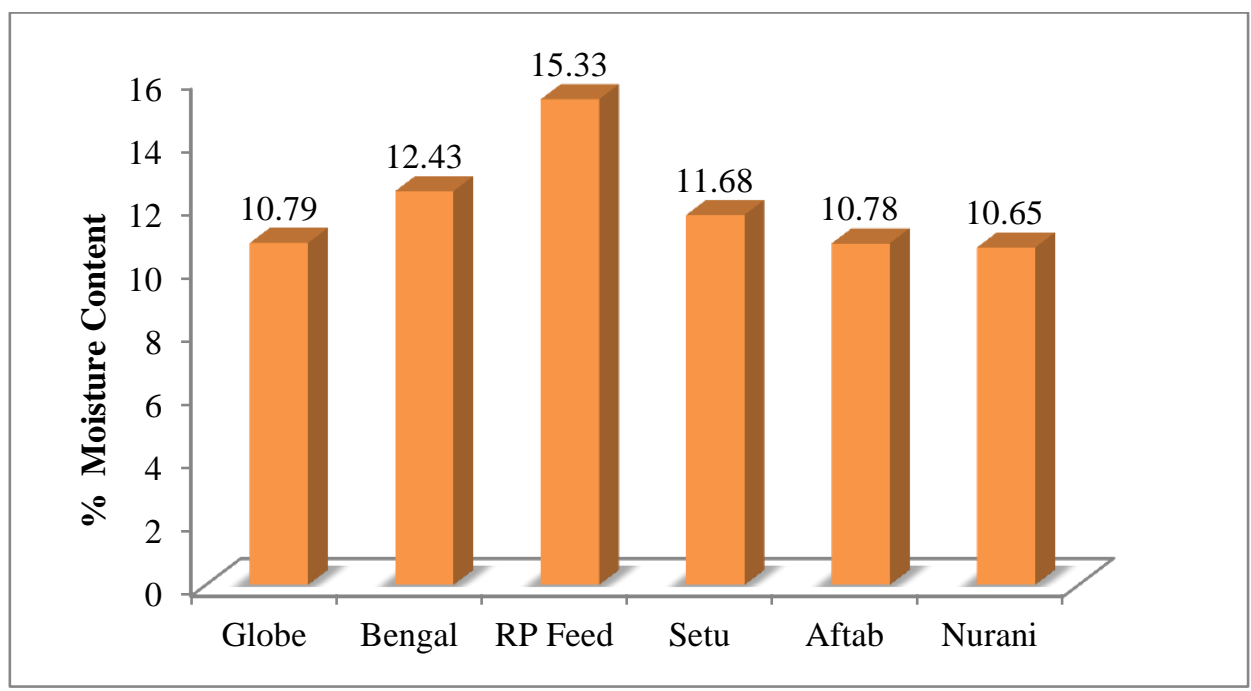

Figure 3. Moisture content of grower feed of different companies.

\subsection{Crude protein content}

A total of 18 feed samples were analyzed to know the actual crude protein content in the experiment. Some feed samples contain more or less similar crude protein percentage as those were labeled by the manufacturers. Others were found having deviated composition from their labeled value. The analyzed mean crude protein content of fish feeds varied from $21.65 \%$ to $34.40 \%$. The lowest mean crude protein containing feed was Mega Finisher having $21.65 \%$ crude protein where the company provided protein value was $26 \%$. The highest mean crude protein containing feed was Globe nursery, having $34.40 \%$ protein which was labeled with $32 \%$ crude protein. Crude protein content of different feeds is shown graphically in the Figure 4 (starter) and Figure 5 (grower). 


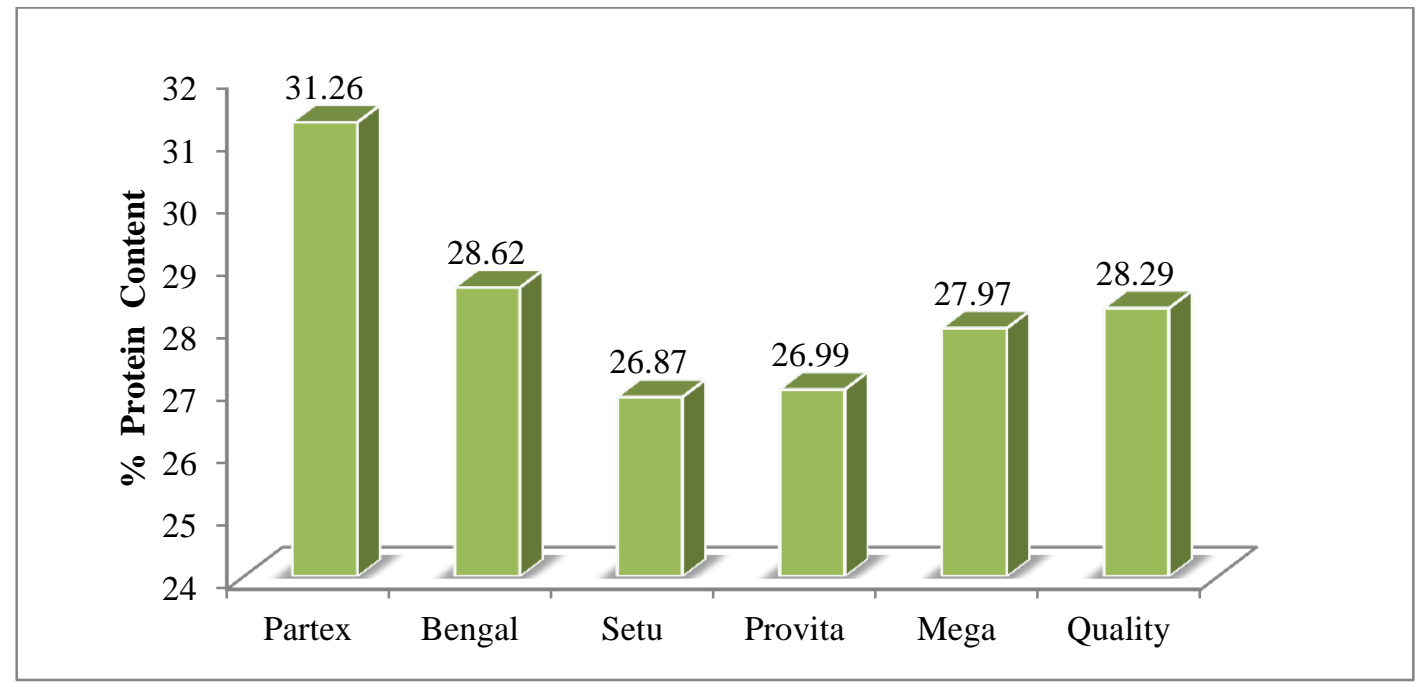

Figure 4. Crude protein content of starter feeds of different companies.

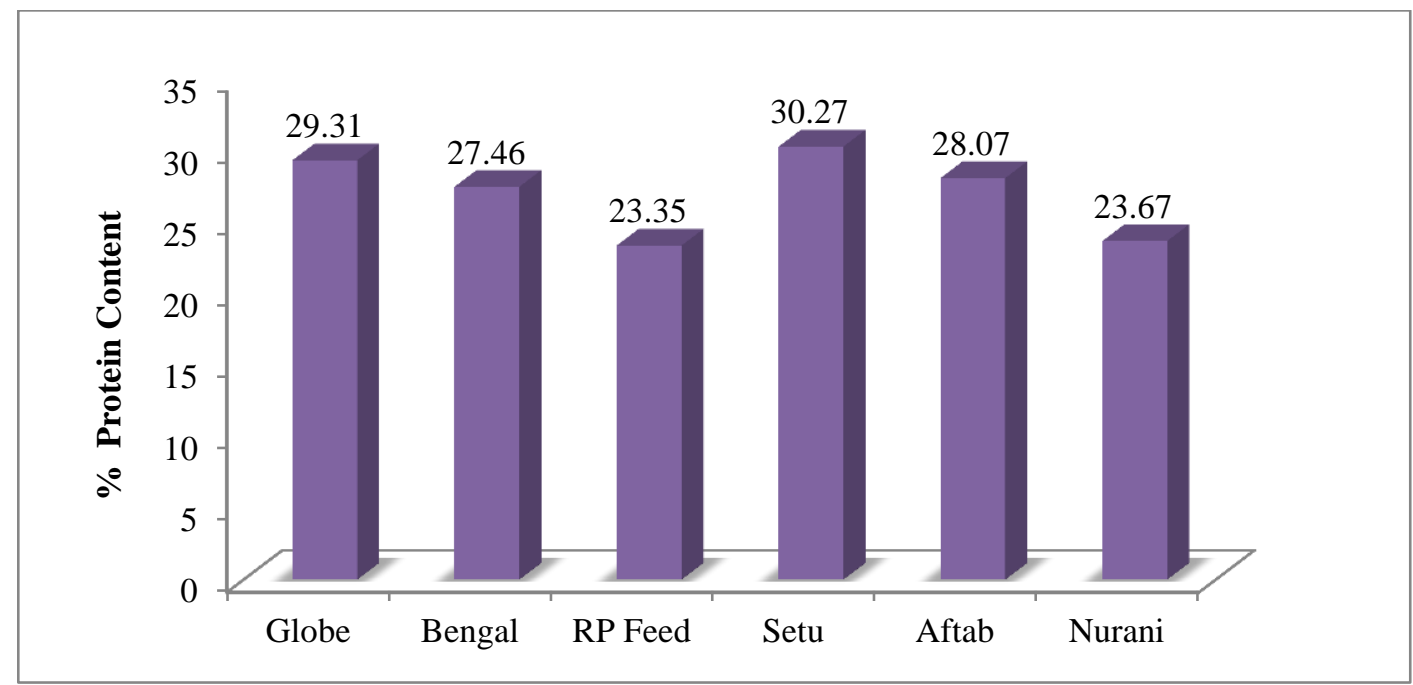

Figure 5. Protein content of Grower feed of different companies

\subsection{Crude lipid content}

In the experiment a total of 18 feed samples were analyzed to know the actual crude lipid content in the feeds. Some feed samples contain more or less similar crude lipid percentage as these were labeled by the manufacturer. Others were found having deviated composition from their labeled value. The analyzed mean crude lipid content of fish feeds varied from $4.33 \%$ to $9.76 \%$. The lowest mean crude lipid containing $4.33 \%$ fiber was found in Setu grower feed where the company provided lipid value was $6 \%$. The highest mean crude lipid containing feed was Provita starter feed having $9.76 \%$ protein which was labeled with $8 \%$ crude lipid. Result shows that neither of the feed companies provides the actual lipid content in their feed. Crude lipid content of different feed companies is shown graphically in the Figure 6 (starter) and Figure 7 (grower). 


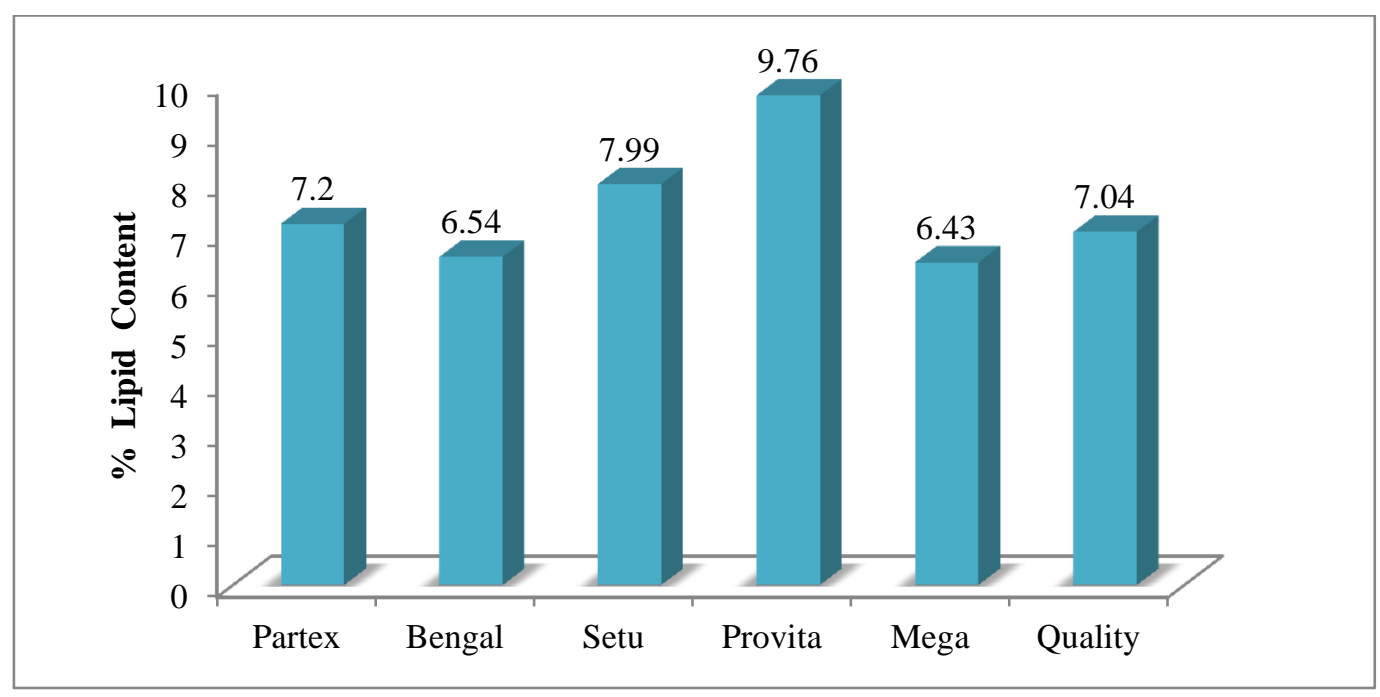

Figure 6. Lipid content of Starter feeds of different companies.

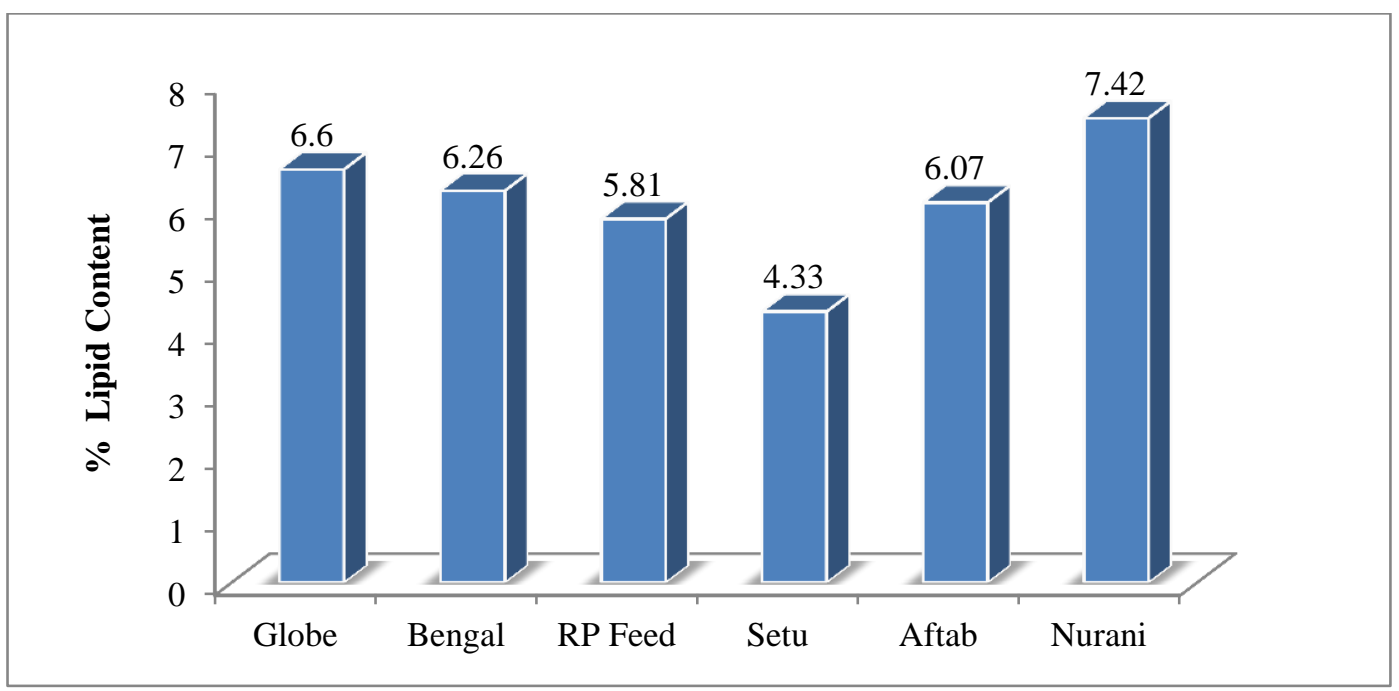

Figure 7. Lipid content of Grower feed of different companies.

\subsection{Ash content}

A total of 18 feed samples were analyzed to know the actual ash content in the experiment. Some feed samples contain more or less similar ash percentage as these were labeled by the manufacturer. Others were found having deviated composition from their labeled value. The analyzed mean ash content of fish feeds varied from $8.29 \%$ to $20.01 \%$. The lowest mean ash containing feed was Aftab grower feed $8.29 \%$, where the company provided ash value was $10 \%$. The highest mean ash containing feed was RP grower feed having $20.01 \%$ ash which was also labeled with $14 \%$ ash. The mean crude ash value of most of the feeds was concentrated within 10-13\%. There had significant difference between analyzed and labeled ash value. Only Mega starter and Setu starter were found having similar value between the labeled and analyzed value. The result of ash content analysis is shown graphically in the Figure 8 (starter) and Figure 9 (grower). 


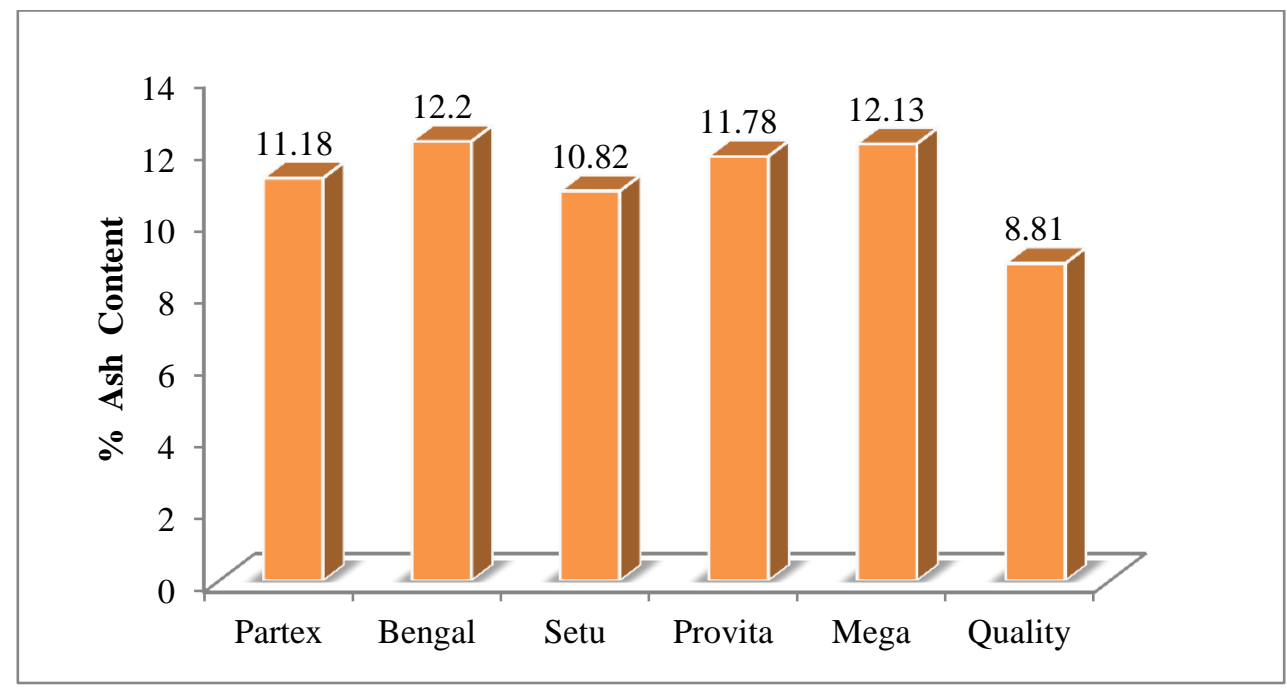

Figure 8. Ash content of Starter feeds of different companies.

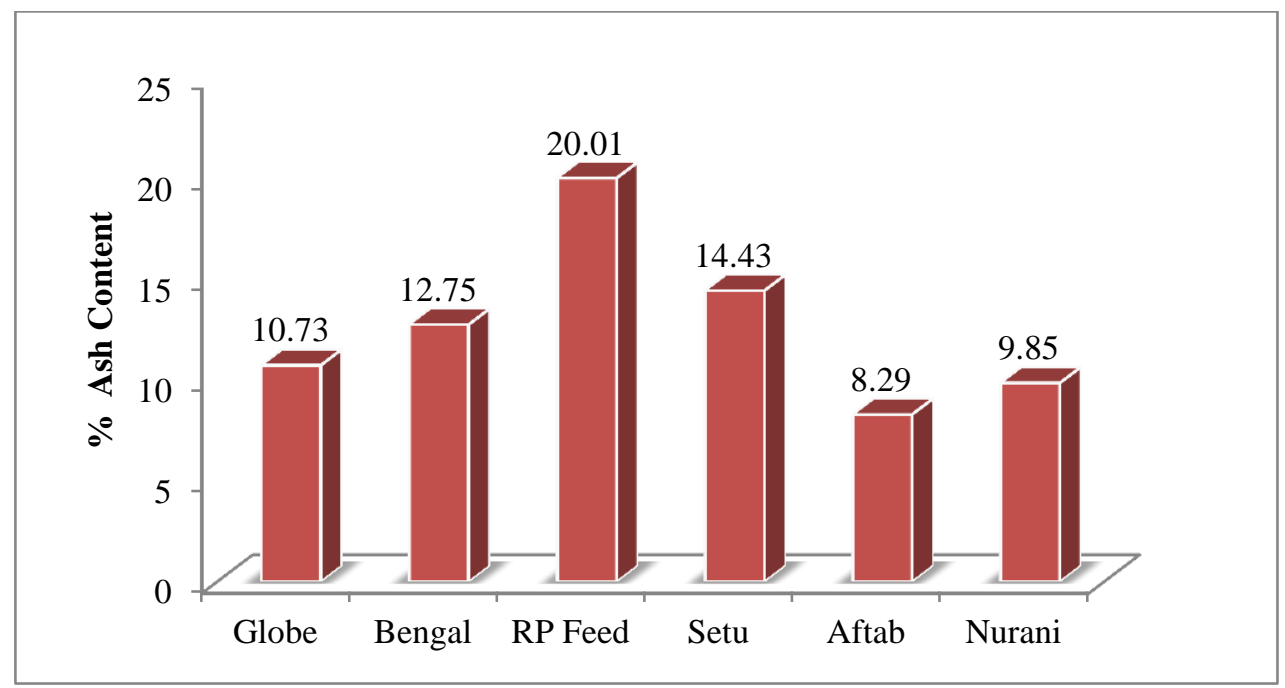

Figure 9. Ash content of Grower feed of different companies.

\subsection{Crude fiber}

In the experiment a total of 18 feed samples were analyzed to know the actual crude fiber content in the feeds. Some feed samples contain more or less similar crude fiber percentage as these were labeled by the manufacturer. Others were found having deviated composition from their labeled value. The analyzed mean crude fiber content of fish feeds varied from $3.60 \%$ to $7.82 \%$. The lowest mean crude fiber containing feed was Globe (nursery) having $3.60 \%$ fiber where the company provided fiber value was $6.00 \%$. The highest mean crude fiber containing feed was Nurani grower having $7.82 \%$ crude fiber which was labeled with $8.00 \%$ crude fiber. Result shows that the analyzed fiber content is more or less similar to the company provided value. Crude fiber content of the feeds is shown graphically in the Figure 10 (starter) and Figure 11 (grower). 


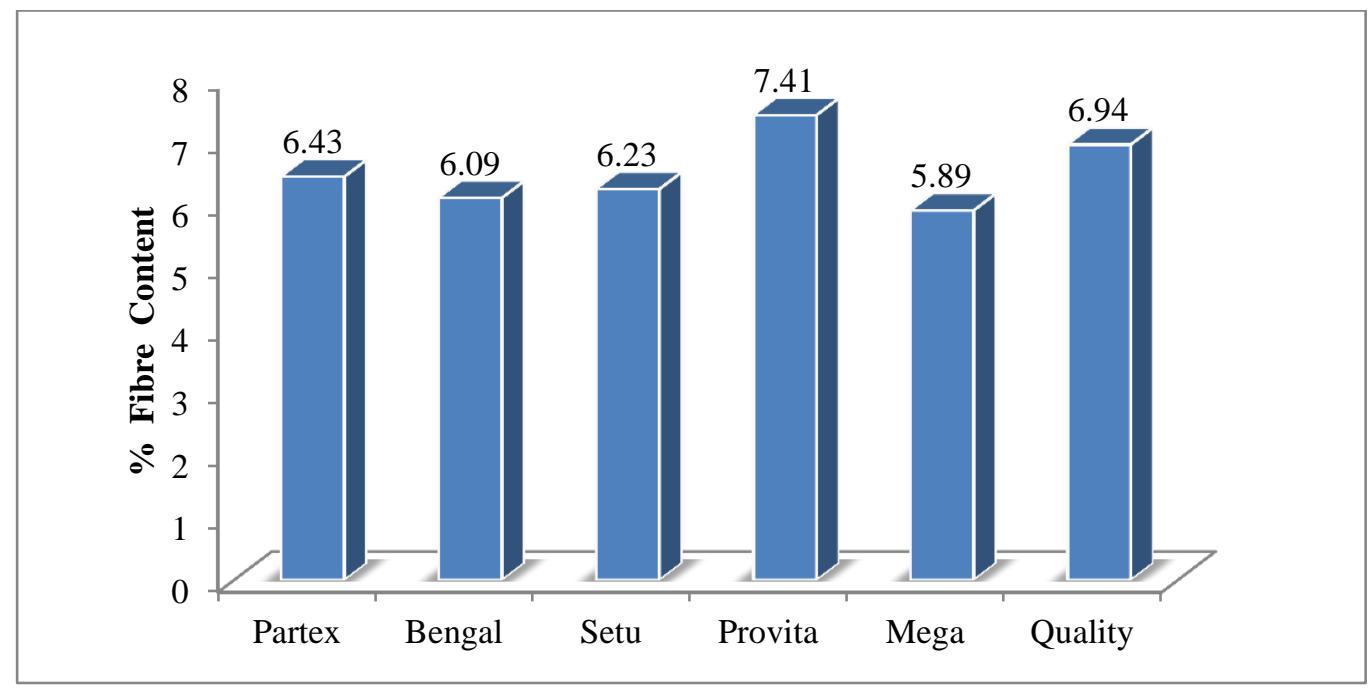

Figure 10. Crude fiber content of starter feeds of different companies.

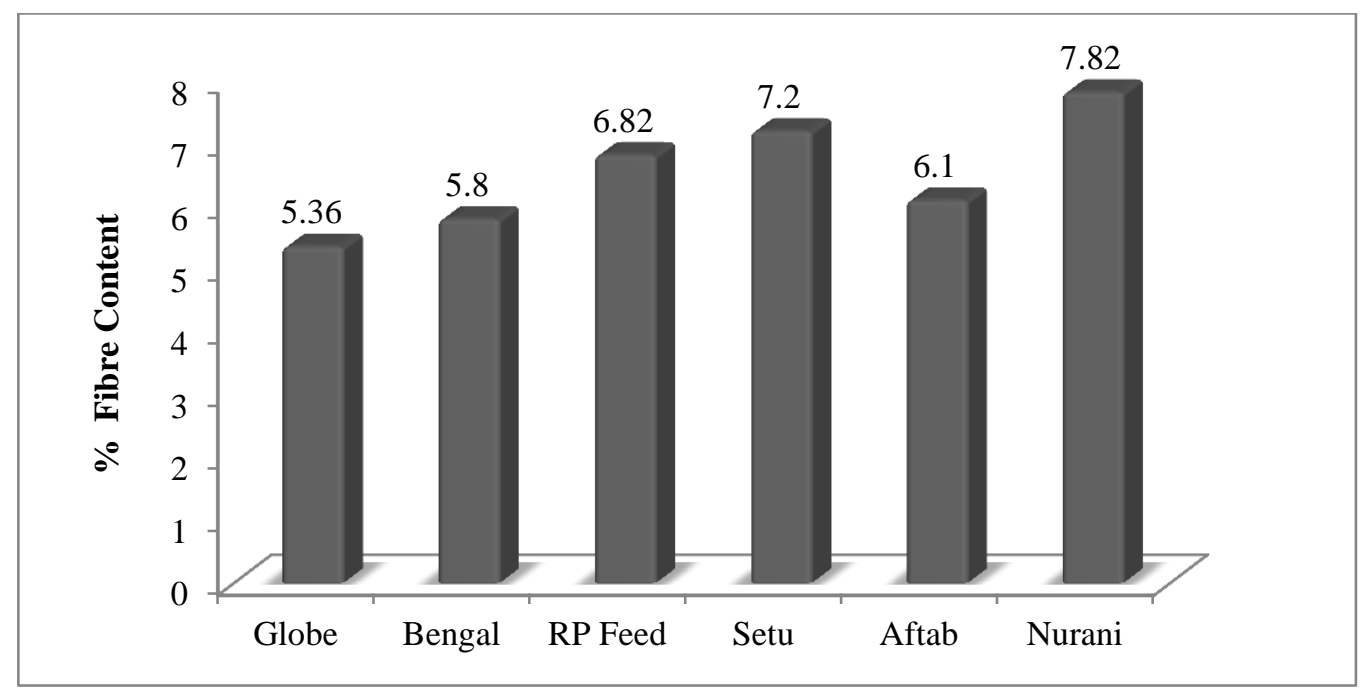

Figure 11. Crude fiber content of grower feed of different companies.

\subsection{Carbohydrates}

A total of 18 feed samples were analyzed to know the actual carbohydrate content in the feeds in the experiment. Some feed samples contain more or less similar carbohydrate percentage as these were labeled by the manufacturer. Others were found having deviated composition from their labeled value. The analyzed carbohydrate content of fish feeds varied from $27.95 \%$ to $36.84 \%$. The lowest carbohydrate containing feed value was found in Abis nursery feed having 27.95\% carbohydrate. The highest carbohydrate containing feed was Provita starter having 36.84\% carbohydrate. Mean carbohydrate content of these feeds was $33.80 \%$. Most of the feeds contain carbohydrates between the range $30 \%$ to $34 \%$ but labeled value of carbohydrates was below $30 \%$ or $30 \%$ in majority of feeds. Carbohydrate content of the feeds is shown graphically in the Figure 12 (starter) and Figure 13 (grower). 


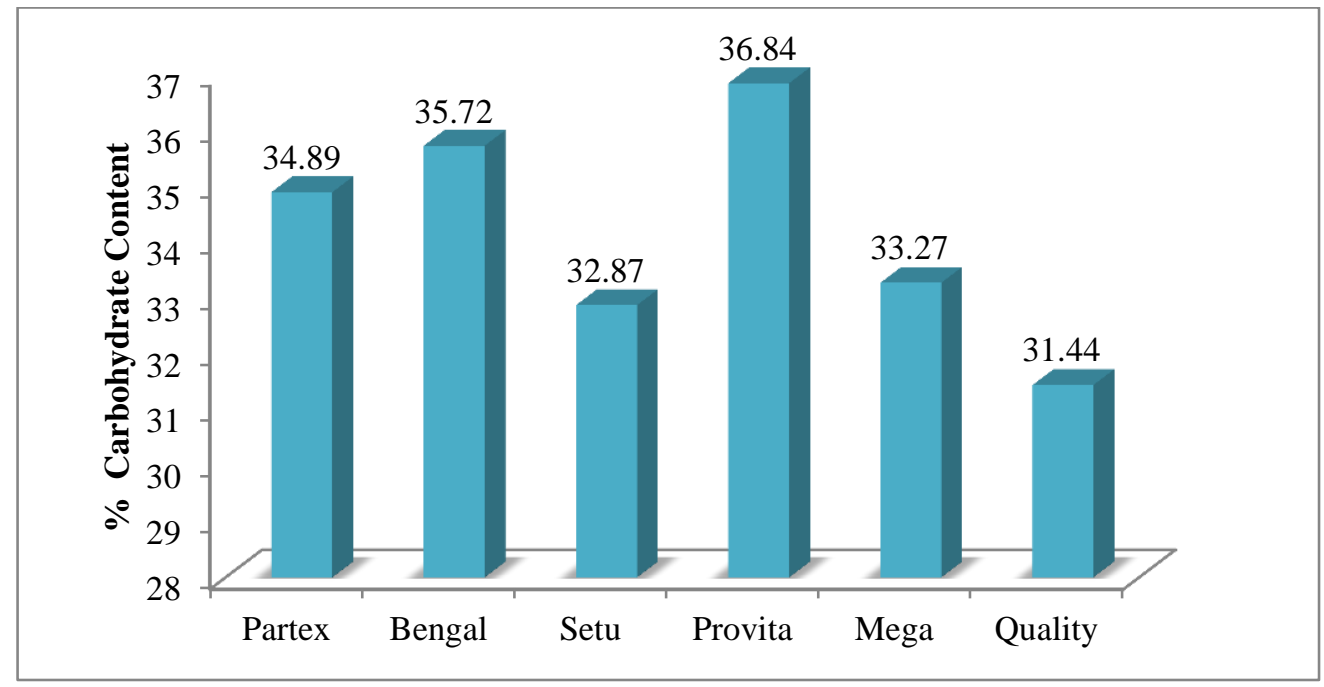

Figure 12. Carbohydrate content of Starter feeds of different companies.

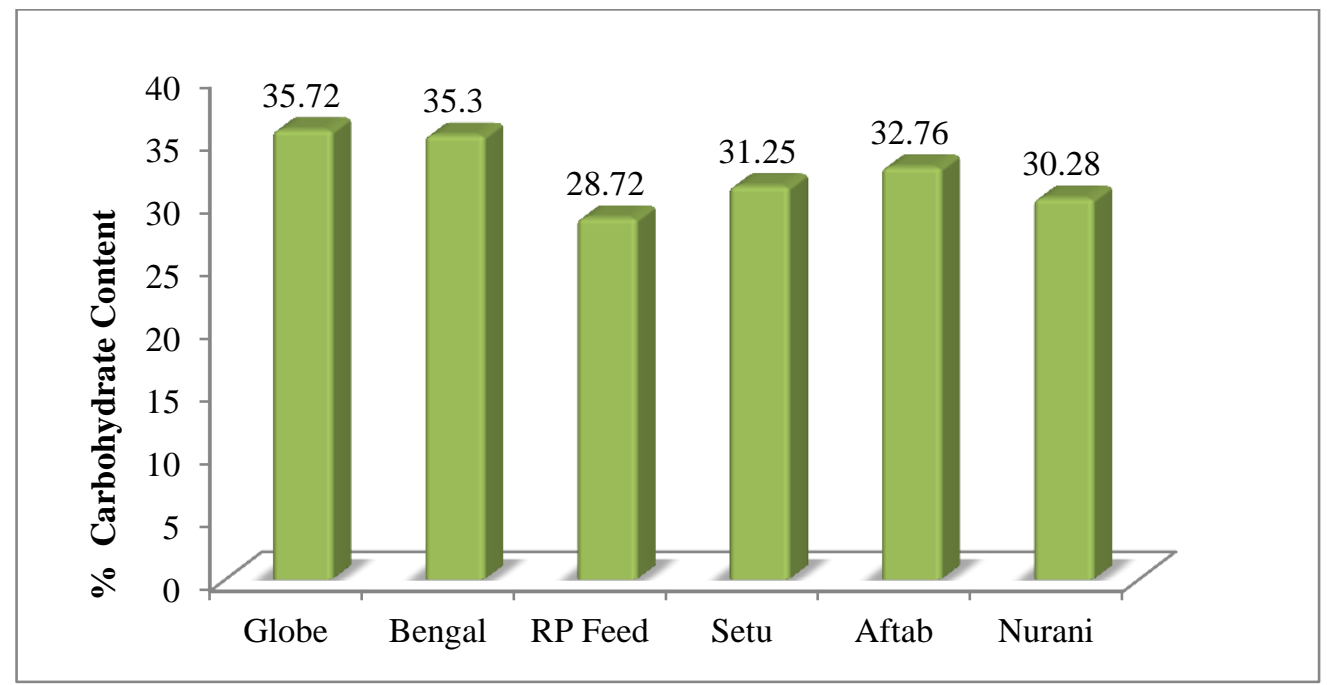

Figure 13. Carbohydrate content of Grower feed of different companies.

\section{Discussion}

Growth, health and reproduction of fish and other aquatic animals are primarily dependent upon an adequate supply of nutrient, both in terms of quantity and quality, irrespective of the culture system in which they are grown. Therefore, supply of inputs (feeds, fertilizers etc.) has to be ensured so that the nutrients and energy requirements of the species under cultivation are met and the production goals of the system are achieved (Hasan, 2001). The moisture value of Partex starter, Partex finisher, Globe nursery, Globe grower, Bengal starter, Bengal grower, Bengal finisher, Setu starter, Setu grower, RP feed grower, Mega nursery, Mega starter, Mega finisher, Aftab grower, Provita starter, Nurani grower, Quality starter, Abis nursery was $11.27 \%, 10.11 \%$, $13.52 \%, 10.79 \%, 11.63 \%, 12.43 \%, 11.59 \%, 13.41 \%, 11.68 \%, 15.33 \%, 8.91 \%, 9.30 \%, 12.14 \%, 10.78 \%$, $12.32 \%, 10.65 \%, 10.14 \%$ and 7.43 respectively. Moisture range in fish feed $8-12 \%$ indicates good quality and most of the manufacturing companies have labeled maximum 10-12\% moisture content in their feed. But in a number of feeds the actual moisture content was more than $12 \%$. A good percentage of moisture containing feeds were Partex starter (11.27\%), Globe Grower (10.79\%), Bengal Starter (11.63\%), Setu Grower (11.68\%) and Aftab grower (10.78\%). Globe nursery, Setu starter and RP grower feed contained more than 13\% moisture. The reasons behind high moisture content may be lack of storage facilities; low quality feed ingredients or long time exposure to highly humid weather. The analyzed mean moisture content of fish feed varied from $7.43 \%$ to 15.33\%. Dry feeds contain 8-10\% moisture while the water content of moist feed ranges from 17 to $40 \%$ or more (Lall, 1991; Zaman et al., 2017; Islam et al., 2017b; Haq et al., 2017; Rahman et al., 2018; Rahman et al., 2019; Biswas et al., 2018 and Yeasmin et al., 2018). Roy (2002) reported that a diet containing 9.8\% moisture appears to be more suitable for GIFT tilapia. Therefore, variation of moisture content in aqua feed among 
different industries was found due to lack of knowledge about moisture or for more profit. Ash value of Partex starter, Partex finisher, Globe nursery, Globe grower, Bengal starter, Bengal grower, Bengal finisher, Setu starter, Setu grower, RP feed grower, Mega nursery, Mega starter, Mega finisher, Aftab grower, Provita starter, Nurani grower, Quality starter, Abis nursery was $11.18 \%, 13.66 \%, 10.98 \%, 10.73 \%, 12.20 \%, 12.75 \%, 11.12 \%$, $10.82 \%, 14.43 \%, 20.01 \%, 16.74 \%, 12.13 \%, 11.48 \%, 8.29 \%, 11.78 \%, 9.85 \%, 8.80 \%$ and $14.65 \%$. The four top most mean ash containing feeds were RP grower, Mega nursery, Abis nursery and Setu grower having 20.01\%, $16.74 \%, 14.65 \%$, and $14.43 \%$ ash respectively. The analyzed ash contents of fish feed varied from $8.29 \%$ to $20.01 \%$. Lowest value of ash $(8.29 \%)$ was found in Aftab grower feed. There had a considerable difference between analyzed and labeled ash value. Labeled ash value of Globe Nursery (14\%), Partex starter (14\%), RP grower (14\%) and Setu grower (14\%), compared to analyzed $10.98 \%, 11.18 \%, 20.01 \%$ and $14.43 \%$ respectively indicate that the manufacturers provide unreliable difference composition of their products. Bhuiyan (2002) found that the diet containing $11.02 \%$ ash appears to be more suitable for carp polyculture. Roy (2002) reported that a diet containing $12.92 \%$ ash appears to be more suitable for GIFT tilapia. The Protein value of Partex starter, Partex finisher, Globe nursery, Globe grower, Bengal starter, Bengal grower, Bengal finisher, Setu starter, Setu grower, RP feed grower, Mega nursery, Mega starter, Mega finisher, Aftab grower, Provita starter, Nurani grower, Quality starter, Abis nursery was 31.26\%, 28.08\%, 34.40\%, 29.31\%, 28.62\%, 27.46\%, 29.95\%, $26.87 \%, 30.27 \%, 23.35 \%, 33.74 \%, 27.97 \%, 21.65 \%, 28.07 \%, 26.99 \%, 23.67 \%, 28.29$ and 31.02 . The highest crude protein containing feeds were Globe nursery (34.40\%), Mega nursery (33.74\%), Partex starter (31.26\%) and Abis nursery $(31.02 \%)$. Labeled values of crude protein were more than the analyzed value except some Feed. The analyzed crude protein content of fish feeds varied from $21.65 \%$ to $34.40 \%$. Lowest crude protein containing feeds were Mega finisher (21.65\%), RP grower (23.35\%), Nurani grower (23.67\%), and Setu starter (26.87\%). The labeled protein values of these feeds were $26 \%, 28 \%, 28 \%$ and $27 \%$ respectively. Result showed that the actual protein content in most of the feeds were always lower than the labeled value. This might be due to using low graded inputs as protein sources. The major and trust source of protein is fish meal, but high price and un-availability of fish meal compels feed manufacturers to use alternate sources of protein. Protein is the major growth promoting factor in feed. The protein requirement of fish is influenced by various factors such as fish size, water temperature, feeding rate, availability and quality of natural foods, overall digestible energy content of diet (Satoh, 2000 and Wilson, 2000). Wilson (2000) reported that most of the commercial catfish feeds contain $32 \%$ crude protein. Roy (2002) reported that a diet containing $27.87 \%$ protein appears to be more suitable for GIFT Tilapia. Hoq et al. (2003) reported that a protein level of $30 \%$ in formulated feed for feeding Tilapia fry in rearing hapas and nursery ponds is suitable. Mollah and Hossain (1990) reported that 39.5\% protein appeared suitable for rearing of C. batrachus. Das et al. (1991) found that the diet containing 38\% protein appears to be more suitable for Labeo rohita fingerlings. Bhuiyan (2002) found that the diet containing $20.71 \%$ protein appears to be more suitable for carp poly-culture. The highest Lipid containing feeds are Provita starter, Mega nursery, Partex finisher and Setu starter feeds contained 9.76\%, 8.98\%, 8.12\% and 7.99\% lipid respectively. Lowest value of lipid $(4.33 \%)$ was found in Setu grower feed. The analyzed crude lipid content of fish feed varied from $4.33 \%$ to $9.76 \%$. Usually in a balanced diet there have a reverse relationship between lipid and protein on their inclusion level. But in the current experiment this relationship was not found. Feeds containing high protein also contain high lipid. An excess of lipid have harmful consequences for fish. In trout four times the required amount slows growth and decreases feed efficiency. The current trend in feeding fish and salmonids in particular, is to increase the lipid content of the feed. This is justified by numerous studies carried out on several species. In the salmonids, it is estimated that an increase in lipid level from 10\% to $20 \%$ allows the protein content to be lowered from $48 \%$ to $35 \%$ without altering growth performance. Wilson (2000) reported that lipid level in catfish feeds should be 5\% to 6\%. On the other hand, Luquet (2000) also stated that dietary lipid levels of 5\% to 6\% are often used in tilapia diet. Roy (2002) reported that a diet containing 9.48\% lipid appears to be more suitable for GIFT tilapia. Crude fiber contents of the experimental sample was 6.43\%, $5.46 \%, 3.60 \%, 5.36 \%, 6.09 \%, 5.80 \%, 4.46 \%, 6.23 \%, 7.20 \%, 6.82 \%, 5.27 \%, 5.89 \%, 6.67 \%, 6.10 \%, 7.41 \%$, $7.82 \%, 6.94 \%$ and $6.23 \%$. The highest five values of crude fiber were found in Nurani grower $(7.82 \%)$, Provita starter (7.41\%), Setu grower (7.20\%), Quality starter (6.94) and RP grower (6.82\%) feed, respectively. The analyzed crude fiber contents of fish feed varied from $3.60 \%$ to $7.82 \%$. Lowest crude fiber containing feed was Globe (Nursery) having 3.60\% fiber. It was observed from the result that feeds that contained more protein had less crude fiber. Bhuiyan (2002) found that the diet containing $13.31 \%$ crude fiber appears to be more suitable for carp poly-culture. Roy (2002) reported that a diet containing $10.75 \%$ crude fiber appears to be more suitable for GIFT tilapia. A certain amount of fiber in feed permits better binding and moderates the passage of feed through alimentary canal. However, it is not desirable to have a fiber content exceeding $10-12 \%$ in diets for fish, as the increase in fiber content would consequently results in the decrease of the quality of an unusable nutrient 
in the diet (De Silva and Anderson, 1995; Zafar et al., 2017; Ali et al., 2016; Rahman et al., 2015; Shabuj et al., 2016; Hossain et al., 2016a). The mean Carbohydrate values of Provita Starter, Bengal Finisher, Bengal Starter and Globe Grower are 36.84\%, 36.03\%, 35.72\% and 34.18\%, respectively having four highest carbohydrate value among 18 feed samples. Lowest value was found in Abis nursery feed (27.95\%). Globe nursery feed contained high moisture and protein percentage and thus contained less carbohydrate. The analyzed carbohydrate contents of fish feed varied from $27.95 \%$ to $36.84 \%$. Ali (2008) found that the diet containing $13 \%$ CHO appears to be more suitable for Nile tilapia. Bhuiyan (2002) found that the diet containing $34.53 \%$ CHO appears to be more suitable for carp polyculture. Roy (2002) reported that a diet containing $29.18 \%$ CHO appears to be more suitable for GIFT tilapia. Jean Guillaume et al. (1999) and Bhuiyan et al. (2018) found that crude energy content of carbohydrates is close to $16.7 \mathrm{KJ} / \mathrm{g}$. when feeding fish, it is important to consider the value of carbohydrates as these values vary considerably. The protein sparing effect of digestible carbohydrates is also subject to much variability. However, the supply of digestible energy by inessential carbohydrates appears to have an overall beneficial effect in terms of improving growth and protein utilization of most fishes.

\section{Conclusions}

In the experiment a total of 18 feed samples were analyzed to know the actual ash content. Some feed samples contain more or less similar ash percentage as these were labeled by the manufacturer. Others were found having deviated composition from their labeled value. The analyzed mean ash content of fish feeds varied from $8.29 \%$ to $20.01 \%$. The lowest mean ash containing feed was Aftab grower feed $8.29 \%$, where the company provided ash value was $10 \%$. The highest mean ash containing feed was RP grower feed having $20.01 \%$ ash which was also labeled with $14 \%$ ash. The mean crude ash value of most of the feeds was concentrated within $10-13 \%$. There had significant deterrence between analyzed and labeled ash value.

\section{Conflict of interest}

None to declare.

\section{References}

Adhikary MR, MA Rahman, AA Asif and RK Adhikary, 2018. Socio-economic status of fish retailers in Jashore sadar, Bangladesh. Asian Australas. J. Food Saf. Secur., 2: 100-108.

Ali MM, AA Asif, MAI Shabuj, S Vaumik, MA Zafar and BMN Sharif, 2016. Status of polyculture Pangasius hypophthalmus with carps in Jhikargacha Upazila of Jessore District, Bangladesh. Int. J. Fish. Aqua. Stud., 4: 423-430.

Ali MSS, M Stead and Houlihan DF, 2008. Effects of dietary protein on growth, food consumption and body composition of Nile tilapia (Oreochromis niloticus). J. Bangladesh Agri. Univ., 6: 99-108.

AOAC, 2000. Official methods of Analysis, Association of Official Analysis Chemists, Washington DC.

Asif AA and MAB Habib, 2017. Socio-economic condition of fish farmers of Jhikargachha upazila in Jessore district, Bangladesh. Asian J. Med. Biol. Res., 3: 462-475.

Asif AA, MA Samad, BMS Rahman, MA Rahman, MH Rahman, SM Yeasmin, and A Nima, 2014. Study on Management of Fish Fry and Fingerling Marketing of Jessore in Bangladesh. Int. J. Bus. Soc. Sci. Res., 2: 127-135.

Asif AA, MA Samad, MH Rahman, MA Farid, SM Yeasmin and BMS Rahman, 2015. Socio-economic condition of fish fry and fingerling traders in greater Jessore region, Bangladesh. Int. J. Fish. Aqua. Stud., 2: 290-293.

Bhuiyan MIA, 2002. Effects of different supplementary feeding methods on growth of fish in carp polyculture, MS Thesis, Department of Aquaculture, BAU, Mymensingh.

Bhuiyan MKA, S Qureshi, MK Abu Hena, S AftabUddin and MAM Siddique, 2016. Proximate chemical composition of sea grapes Caulerpa racemosa (J. Agardh, 1873) collected from a sub-tropical coast. Virology and Mycology, 5: 1000158.

Bhuiyan MRR, H Zamal, MM Billah, MS Bhuyan, AA Asif and MH Rahman, 2018. Proximate composition of fish feed ingredients available in Shibpur Upazila, Narsingdi district, Bangladesh. J. Entom. Zool. Stud., 6: 1345-1353.

Biswas C, MMM Hossain, AA Asif, B Sarker, MM Billah and MA Ali, 2018. Culture strategies, diseases and their mitigations in mono-sex Nile tilapia farming in Jessore sadar region, Bangladesh. Asian Australas. J. Biosci. Biotechnol., 3:190-200. 
Das KMS, N Mohanty and S Sarkar, 1991. Optimum dietary protein to energy ratio for Labeo rohita fingerlings. In SS De Silva (editor), Fish nutrition research in Asia. Proceedings of the Fourth Asian Fish Nutrition Workshop. Asian Fish. Soc. Spec. publ. 5, pp. 205.

DeSilva SS and TA Anderson, 1995. Fish Nutrition in Aquaculture. Chapman and Hall. pp. 208.

DoF, 2016. Department of Fisheries, Code of Conduct for Selected segments of the Aquaculture Industry in Bangladesh,

FAO, 2016. The state of world fisheries and aquaculture. Available: http://www.fao.org/3/a-i5555e.pdf

Haq ME, M Rahman, A Hossain, AA Asif, H Rahman, P Chwakravorty, A Satter and MS Islam, 2017. Comparative growth performance between monosex and natural XY male tilapia in Noakhali region, Bangladesh. Asian J. Med. Biol. Res., 3: 391-397.

Hasan MT, 2010. Quality assessment of fish feed of different feed companies marketed in Mymensingh region, MS Thesis, Department of Aquaculture, Bangladesh Agricultural University, Mymensingh.

Hoq ME, AHM Kohinoor, MA Hossain, MZ Ali, MM Islam and MN Khan, 2003. In: MA Mazid and MA Hossain (Editors). A manual on fish and shrimp feed formulation and application. Bangladesh Fisheries Research Institute, Mymensingh. pp. 46.

Hossain MD, A Hossain, H Rahman, M Rahman, AA Asif, MM Billah and MAI Mondal, 2018. Marketing channels of mud crab (Scylla serrata) at Nijhum Dwip, Noakhali, Bangladesh: A value chain analysis. J. Entom. Zool. Stud., 6: 521-527.

Hossain MT, MS Alam, MH Rahman, AA Asif and SM Rahmatullah, 2016a. Present status of Indian major carp broodstock management at the hatcheries in Jessore region of Bangladesh. Asian Australas. J. Biosci. Biotechnol., 1:362-370.

Hossain MZ, A Pal, MA Hasan, MS Parvej, N Nahar and AA Asif, 2016b. Nutritional status and sociodemographic characteristics of the people of south-west coastal region in Bangladesh. Asian Australas. J. Biosci. Biotechnol., 1: 323-332.

Islam FMK, AA Asif, M Ahmed, MS Islam, B Sarker, MA Zafar and M Rahman, 2017a. Performances of resource poor households in aquaculture practices in sadar upazila, Meherpur, Bangladesh. Int. J. Fish. Aqua. Stud., 5: 281-288.

Islam MA, AA Asif, MA Samad, BMS Rahman, MH Rahman, A Nima and SM Yeasmin, 2014. Socioeconomic conditions of the fish farmers in Jessore, Bangladesh. Int. J. Bus. Soc. Sci. Res., 2: 153-160.

Islam MM, AA Asif, S Vaumik, MA Zafar, BMN Sharif, MH Rahman and S Shahriyar, 2015. Socio economic status of fry collectors at Sundarban region. Int. J. Fish. Aqua. Stud., 3: 89-94.

Islam MS, AA Asif, B Sarker, A Satter, M Ahmed, M Rahman, MA Zafar and SM Rahmatullah, 2017b. Fry production and its marketing system of North-West fisheries extension project at Parbatipur, Dinajpur, Bangladesh. Asian J. Med. Biol. Res., 3: 368-378.

Jacobs MB, 1973. The Chemical Analysis of Food Products. 3 ed. New York: Robert Krieger, Publishing Co., 80.

Lall SP, 1991. Concepts in the formulation and preparation of a complete fish diet. In SS De Silva (ed.), Fish nutrition research in Asia. Asian Fisheries Society, Manila, Philippines, pp. 205.

Luquet P, 2000.Tilapia, Oreochromis sp. In: RP Wilson. (Editor) Handbook of Nutrient Requirement of Finfish. CRC Press, Boca Raton Ann Arbor, London, pp. 169-180.

Maynard J, 1970. Methods of Food Analysis, Academic Press, New York, NY., pp. 163.

Mitchell P, 1972. Chemiosmotic coupling in energy transduction: A logical development of biochemical knowledge. Journal of Biology, 3:5-24.

Mollah MFA and MA Hossain, 1990. Effects of artificial diets containing different protein levels on growth and feed efficiency of catfish (Clarias batrachus). Indian J. Fish., 37: 251-259.

Mondal MAI, MA Kader, AH Choudhury, MG Mustafa, MRU Nabi, MM Billah, AA Asif and AAM Siddiqui, 2018. Socio-economic uplifting analysis of ESBN fishery of the coastal villages, Kumira and Kattoli, Chittagong, Bangladesh. Int. J. Res. Granth., 6: 248-263.

Pearson T, G Galfre, A Ziegler and Milstein C, 1977. A myelomahybrid-producing antibody specific for an allotypicdeterminant on IgD-like molecules of the mouse. European Immunology, 7: 684-690.

Rahaman MM, MA Zafar, BMN Sharif, P Paul, AA Asif, MM Islam and MI Hossain, 2015. Tilapia (Oreochromis mossambicus) marketing system in greater Jessore region, Bangladesh. Int. J. Fish. Aqua. Stud., 3: 95-103.

Rahman MH, MA Rahman, MMM Hossain, SM Yeasmin and AA Asif, 2015. Effect of feeding management of broodstock on breeding performance of bata (Labeo bata). Asian J. Med. Biol. Res., 1:553-568. 
Rahman MH, SM Yeasmin, MA Rahman, MA Farid and AA Asif, 2019. Effect of formalin on fertilization, hatching rate of eggs of Thai Pangas (Pangasius hypophthalmus) and survival and growth performance of fry. Int. J. Biosci., 14: 158-165.

Rahman MM, MMM Hossain, MM Billah, AA Asif and J Ferdous, 2018. Growth of freshwater mud eel (Monopterus cuchia) in different water condition, feeds and probiotics. Int. J. Bus. Soc. Sci. Res., 7: 10-17.

Razeim MA, MG Farouque, MA Sarker, AA Asif and M Ahmed, 2017. Attitude of farmers towards Pangas farming for their livelihood improvement. Asian Australas. J. Biosci. Biotechnol., 2: 106-119.

Roy R, 2002. Effects of stocking density on the growth and survival of GIFT tilapia feed on formulated diet. MS Thesis, Department of Aquaculture, Bangladesh Agricultural University, Mymensingh.

Satoh S, 2000. Common carp, Cyprinus carpio. In RP Wilson (Editor). Handbook of Nutrient Requirement of Finfish. CRC Press, Boca Raton Arbor, Boston, London, pp. 55-68.

Shabuj MAI, AA Asif, O Faruq, MR Bari and MA Rahman, 2016. Brood stock management and induced breeding of Thai Pangus (Pangasius hypophthalmus) practiced in the hatcheries of Jessore region, Bangladesh. Int. J. Bus. Soc. Sci. Res., 4:235-246.

Sharif BMN, AA Asif, S Vaumik, MA Zafar, MM Islam and MA Samad, 2015. Socio-economic condition of fish farmer and trader at the village of Pitamborpur in Chaugachha upazilla in Jessore, Bangladesh. Int. J. Fish. Aqua. Stud., 3: 212-217.

Sultana N, AA Asif, MMI Dihider, SM Ahsan and FS Maraj, 2015. Usefulness of farm women training programmes in livelihood security. Int. J. Bus. Soc. Sci. Res., 4: 13-24.

Vaumik S, SK Sarker, MS Uddin, MT Alam, A Satter, AA Asif, 2017. Constraints and prospects of fish farming in Lalmonirhat District. Int. J. Bus. Soc. Sci. Res., 5: 201-210.

Wilson RP, 2000. Channel catfish, Ictalurus puntatus. In: RP Wilson (Editor), Handbook of Nutrient Requirement of Finfish. CRC Press, Boca Raton Ann Arbor, Boston, London, pp. 35-53.

Yeasmin MY, Rahman H, Rahman A, AA Asif, Farid A and Billah M, 2018. Influence of feeding administration of brood-stock on breeding performance of Common Carp (Cyprinus carpio Linnaeus, 1758). J. Aquacul. Eng. Fish. Res., 4:127-137.

Zafar MA, MZ Hasan, MM Ali and AA Asif, 2017. Growth and production performance of Vietnamese koi (Anabas testudineus) with Magur (Clarias batrachus) at different stocking densities. Asian Australas. J. Biosci. Biotechnol., 2:226-237.

Zaman MFU, MA Samad, MA Islam, MHU Jaman, S Khondoker and AA Asif, 2017. Assessment of sustainability of Pangasius (Pangasius hypophthalmus) farming at Jhikargachha Upazila in Jessore district, Bangladesh. Int. J. Fauna Biol. Stud., 4:109-119. 